\title{
Sex differences in the association between educational level and specific domains of physical activity: a Brazilian cross-national survey
}

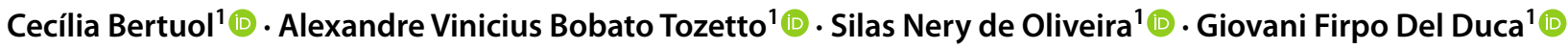

Received: 20 October 2020 / Accepted: 2 November 2021 / Published online: 6 January 2022

( ) The Author(s), under exclusive licence to The Canadian Public Health Association 2021

\begin{abstract}
Objective To identify the association between educational level and physical activity (PA) in specific domains according to sex, among residents of 26 Brazilian state capitals and the Federal District.

Methods This is a cross-national survey, with data obtained from the Telephone-based Surveillance of Risk and Protective Factors for Chronic Diseases (VIGITEL), in 2017, conducted with individuals $\geq 18$ years old $(n=53,034)$. The education level (classified as $\leq 4$ years, 5 to 8 years, 9 to 11 years, and $\geq 12$ years of education) and PA of participants (meeting PA recommendations and performing this active behaviour) in the commuting, domestic, leisure, and work domains were selfreported. Binary logistic regression was used to analyze the data obtained from the survey.

Results Males and females with higher education were less likely to meet PA recommendations (males: OR $=0.68$ [95\% CI 0.52-0.91]; females: $\mathrm{OR}=0.41$ [0.34-0.48]) and perform the active behaviour (males: $\mathrm{OR}=0.73$ [0.57-0.93]; females: $\mathrm{OR}=0.27[0.23-0.32]$ ) in the domestic domain. In the work domain, the two outcomes were associated with education only for males, indicating that those with more years of education had less chance of meeting PA recommendations $\left(\mathrm{OR}_{9}\right.$ to 11 years $\left.=0.61[0.46-0.83] ; \mathrm{OR}_{\geq 12 \text { years }}=0.21[0.15-0.30]\right)$ and performing it $\left(\mathrm{OR}_{9}\right.$ to 11 years $=0.64[0.49-0.84]$; $\left.\mathrm{OR}_{\geq 12 \text { years }}=0.25[0.18-0.34]\right)$. However, more years of education seemed to positively influence meeting PA recommendations (males: $\mathrm{OR}_{9-11 \text { years }}=2.26$ [1.79-2.87]; $\mathrm{OR}_{\geq 12 \text { years }}=2.91$ [2.28-3.72]; females: $\mathrm{OR}_{5-8}$ years $=1.26$ [1.04-1.54]; $\mathrm{OR}_{9-11 \text { years }}=1.81[1.52-2.16] ; \mathrm{OR}_{\geq 12 \text { years }}=2.69[2.25-3.22]$ ) and practicing this behaviour (males: $\mathrm{OR}_{5-8 \text { years }}=1.29[1.01-$ $1.63] ; \mathrm{OR}_{9-11 \text { years }}=2.54$ [2.04-3.17]; $\mathrm{OR}_{\geq 12 \text { years }}=3.31$ [2.64-4.16]; females: $\mathrm{OR}_{5-8 \text { years }}=1.23$ [1.03-1.46]; $\mathrm{OR}_{9-11 \text { years }}=1.75$ $[1.51-2.01] ; \mathrm{OR}_{\geq 12 \text { years }}=2.94$ [2.53-3.40]) in leisure time for both sexes.
\end{abstract}

Conclusion Education level appears to be an important determinant in the relationship with PA in its different domains, especially in the leisure and domestic domains, for both sexes.

\begin{abstract}
Résumé
Objectif Identifier l'association entre le statut éducatif et l'activité physique (AP) dans des domaines spécifiques, selon le sexe, chez les résidents des capitales du Brésil et du District Fédéral.

Méthodes Il s'agit d'une enquête transnationale dérivée de la surveillance téléphonique des facteurs de risque et de protection pour les maladies chroniques (VIGITEL), menée en 2017, auprès de personnes âgées de $\geq 18$ ans $(n=53$ 034). Le niveau d'éducation ( $\leq 4$ ans, 5 à 8,9 à 11 et $\geq 12$ ans d'étude) et l'AP des participants (respecter les recommandations d'activité physique et adopter ce comportement actif) dans les domaines des déplacements domicile-travail, domestique, des loisirs et du travail ont été autodéclarés. Une régression logistique binaire a été utilisée.

Résultats Les hommes et les femmes ayant fait des études supérieures étaient moins susceptibles de respecter les recommandations de l'AP (hommes : $\mathrm{RC}=0,68$ [IC95\% 0,52-0,91]; femmes : RC $=0,41$ [0,34-0,48]) et d'adopter un comportement actif (hommes : $\mathrm{RC}=0,73$ [0,57-0,93]; femmes : $\mathrm{RC}=0,27[0,23-0,32]$ ) dans le domaine domestique. Dans le domaine du travail, les deux résultats n'étaient associés à l'éducation que pour les hommes, indiquant que ceux qui avaient plus d'années d'éducation avaient moins de chances de respecter les recommandations de l'AP $\left(\mathrm{RC}_{9 \text { a } 11 \text { ans }}=0,61\right.$ $\left.[0,46-0,83] ; \mathrm{RC}_{\geq 12 \text { ans }}=0,21[0,15-0,30]\right)$ et de les exécuter $\left(\mathrm{RC}_{9 \text { a } 11 \text { ans }}=0,64[0,49-0,84] ; \mathrm{RC}_{\geq 12 \text { ans }}=0,25[0,18-0,34]\right)$.
\end{abstract}

Extended author information available on the last page of the article 
Cependant, plus d'années d'éducation semblent influencer positivement le respect des recommandations de l'AP (hommes : $\mathrm{RC}_{9 \mathrm{a} 11 \text { ans }}=2,26$ [1,79-2,87]; $\mathrm{RC}_{\geq 12 \text { ans }}=2,91$ [2,28-3,72]; femmes : $\mathrm{RC}_{5 \text { a } 8 \text { ans }}=1,26$ [1,04-1,54]; $\mathrm{RC}_{9 \text { a } 11 \text { ans }}=1,81[1,52-2,16] ;$ $\mathrm{RC}_{\geq 12 \text { ans }}=2,69[2,25-3,22]$ ) et la pratique de ce comportement (hommes : $\mathrm{RC}_{5 \text { a } 8 \text { years }}=1,29[1,01-1,63] ; \mathrm{RC}_{9 \text { a } 11 \text { ans }}=2,54$ $[2,04-3,17] ; \mathrm{RC}_{\geq 12 \text { ans }}=3,31$ [2,64-4,16]; femmes : $\mathrm{RC}_{5 \text { a } 8 \text { ans }}=1,23[1,03-1,46] ; \mathrm{RC}_{9 \mathrm{a} 11 \text { ans }}=1,75[1,51-2,01] ; \mathrm{RC}_{\geq 12 \text { ans }}=2,94$ $[2,53-3,40])$ pendant les loisirs pour les deux sexes.

Conclusion Le niveau d'éducation semble un déterminant important de la relation avec l'AP dans ses différents domaines, notamment dans les domaines des loisirs et domestique, pour les deux sexes.

Keywords Lifestyle $\cdot$ Motor activity $\cdot$ Educational status $\cdot$ Public health surveillance $\cdot$ Cross-sectional studies

Mots-clés Activité motrice $\cdot$ statut scolaire $\cdot$ surveillance de la santé publique $\cdot$ études transversales

\section{Introduction}

The adoption of healthy lifestyles, such as regular physical activity (PA), is identified as a relevant factor for the prevention and non-drug treatment of noncommunicable chronic diseases (NCDs) and for the improvement of quality of life (Johnson \& Acabchuk, 2018). Although the benefits derived from this active behaviour are mentioned in the literature (Kohl et al., 2012), with a gradual increase in programs implemented to stimulate healthy behaviours (Abu-Omar et al., 2017), epidemiological research reveals that a considerable portion of the adult population does not meet the recommendations for accumulated PA levels in different domains (Guthold et al., 2018). Therefore, we highlight the need to understand active behaviour in different domains (leisure, commuting, work/occupational, and domestic) to develop appropriate strategies for improving the pre-existing scenario.

Studies have explored each PA domain because a wide variation exists across countries with different income levels (Bauman et al., 2012; Del Duca et al., 2015), in addition to other determinants such as demographics and socioeconomic factors. For instance, active commuting and occupational PA may be more frequent in low- and middle-income countries, and as socioeconomic status improves, active transport decreases (Bauman et al., 2012). In contrast, leisure time PA may be predominant in high-income countries (Bauman et al., 2012).

Moreover, the consideration of socioeconomic gradients has gained importance, as they are associated with active behaviour (O'Donoghue et al., 2018). This is because inequality of power, income, assets, and services contributes to health conditions and problems, as well as high mortality rates (Marmot et al., 2008). Thus, one's level of education could be used as a form of measurement in the scientific environment, given that this variable is relatively stable during adulthood, appropriately reflects the socioeconomic status of the population under consideration, and is easily verified (Gidlow et al., 2006). In this context, the level of PA in different domains seems to differ according to the education levels of individuals (O'Donoghue et al., 2018;
Scholes \& Bann, 2018); in some cases, education is a more important determinant than race and ethnicity, for domains such as leisure and work PA (He \& Baker, 2005). In addition, higher levels of education may be associated with less disagreement between direct or indirect PA measures, such as using devices or obtaining self-reports, respectively (Gorzelitz et al., 2018). In general, associations between PA and education level tend to be stronger than those between PA and income or social classification by occupation (Gidlow et al., 2006).

In Brazil, the education level of both males and females has increased in recent years, and the illiteracy rate has decreased (Pinto Junior et al., 2019). Meanwhile, regional and social inequalities have decreased in the areas of oral healthcare and mammography (Viacava et al., 2019). However, inequalities in educational level (Mahlmeister et al., 2019) and health (Viacava et al., 2019) indicators persist between sexes. Schooling still seems to be influenced by sexrelated characteristics, reflecting a long-standing sexist society, consequently resulting in a workforce massively represented by males. Thus, sex and education can be considered important determinants of PA. Therefore, knowing the life situations, habits, and behaviours of individuals and identifying the more vulnerable subgroups can broaden discussions for public health promotion policies for the different domains of PA. Moreover, this can help in the planning and execution of interventions that focus on promoting healthy lifestyles, considering that the quality and quantity of years of education can greatly contribute to individual awareness and better life habits. For this, it is important to recognize that other factors, such as demographic variables (e.g., age, marital status, or regions of Brazil) and behavioural variables (e.g., PA in different domains), can also influence the relationship between PA and education (Bauman et al., 2012; O’Donoghue et al., 2018).

Given the above, the present study aimed to identify the association between educational status and PA in specific domains (commuting, domestic, leisure, and work) for male and female residents of the 26 capitals of Brazil and the Federal District. 


\section{Methods}

This was a cross-sectional study using data obtained from the Telephone-based Surveillance of Risk and Protective Factors for Chronic Diseases (VIGITEL), conducted in 2017. The VIGITEL system is composed of probabilistic samples of the adult population ( $\geq 18$ years old) who reside in the 26 Brazilian state capitals and the Federal District and have at least one fixed telephone line in their homes.

The VIGITEL sampling process was developed in two phases. The first phase was based on the systematic and stratified drawing by zip code of at least 5000 telephone lines per city. In the second phase, one of the adults residing at each home was selected to participate in the interview. Lines representing companies that no longer existed or were out of service, as well as lines that did not answer after six call attempts, were not eligible for the survey. Additional information on methodological aspects can be found in previously published material (Brasil, 2018).

The data collection took place from January to December 2017. As a research instrument, we used a questionnaire formulated from other tools applied by risk factor monitoring systems for chronic diseases and from experiences through system implementation tests conducted in some Brazilian cities (Brasil, 2018).

The outcome variables took into account the minutes of PA practised per week in specific domains, such as commute (walking or cycling to and from work or school), domestic, leisure, and work; the participants were categorized in two distinct ways. First, they were classified as inactive or active, according to their compliance with PA recommendations ( $\geq 150 \mathrm{~min} /$ week of moderate intensity or $\geq 75 \mathrm{~min} /$ week of vigorous intensity PA, for active participants). It is noteworthy that the creation of this variable was based on questions related to the frequency, duration, and intensity of activities, based on the compendium of Ainsworth et al. (2000). The minutes per week of vigorous PA was multiplied by 2 . Subsequently, it was only considered whether the individual performed the activity in the specific domains, taking into consideration that 'some physical activity is better than none' as claimed by the new World Health Organization Guidelines on Physical Activity and Sedentary Behaviour (WHO, 2020). The indicators of PA seemed reliable and sufficiently accurate (Monteiro et al., 2008). As an independent variable, details of education level were collected through the grades of the participants and were classified as years of education ( $\leq 4$ years, 5 to 8 years, 9 to 11 years, and $\geq 12$ years of education). The present categories for this variable were created while considering the education system of Brazil. Thus, those who studied for ' $\leq 4$ years' were considered illiterate or individuals with complete or incomplete early childhood education. The ' 5 to 8 years' category represented individuals with complete or incomplete elementary school education; ' 9 to 11 years' consisted of those with complete or incomplete high school education; ' $\geq 12$ years' included adults who completed all school grades and had complete or incomplete higher education, or a postgraduate degree. All questions, answer options, and categorization of variables used in the present study can be found in the supplementary material. The Portuguese version of the questionnaire applied to participants can be found in a previously published report (Brasil, 2018). All interviews were conducted through telephonic exchange, the calls were recorded, and data quality control was subsequently performed.

Data analysis considered the weighting of VIGITEL, incorporating three factors: the inverse number of telephone lines in the respondents' home, the number of adults in the respondents' home, and post-stratification weight regarding the characteristics of sex, age, and education of the sample and of the total population of the Brazilian capitals. Prevalence for each PA domain and comparisons between educational levels were based on relative frequency and 95\% confidence intervals (CI). Subsequently, binary logistic regression was used to verify the association between meeting PA recommendations and performing PA (does not perform versus performs) in the different domains, as well as education levels, with the results expressed in odds ratio (OR). Age, marital status, regions of Brazil, and the other domains of PA were used as adjustment variables for the analyses and added simultaneously to the model (at the same hierarchical level). The backward selection technique was adopted and a critical level of $p \leq 0.20$ was set in order to remain in the statistical model, with the intention of controlling possible confounding factors. It is important to highlight that all analyses were stratified by sex, considering that PA in the various domains is different for males and females. Data were analyzed using Stata ${ }^{\circledR}$ Standard Edition statistical software, version 13.0 (Stata Corp LP, United States).

\section{Results}

In 2017, VIGITEL made calls to 125,400 telephone lines distributed among 627 replicas, identifying 75,545 eligible lines. In the end, 53,034 interviews were conducted, indicating a system success rate of $70 \%$. The loss of approximately $30 \%$ of the telephone lines was due to the impossibility of making initial contact with its users (either busy and unanswered lines or connected to the answering machine) or not 
finding the selected individual at home. Refusal to participate in the interview was observed in $4.6 \%$ of the eligible lines.

Of the 19,504 males participating in the study ( $46 \%$ of the total sample), $84.7 \%$ were adults under 60 years, $38.8 \%$ studied for a period of 9 to 11 years, and $44.6 \%$ were from the Southeast. Of the 33,530 females, $80.5 \%$ were under 60 years old, $36 \%$ studied for a period of 9 to 11 years, and $45 \%$ lived in the Southeast. The average age of all participants was $42.4 \pm 14.1$ years. Details of the male and female participants' demographic and social characteristics can be found in Table 1.
Figure 1 presents the prevalence of meeting PA recommendations and performing active behaviour according to specific domains for males and females. A similar profile was observed between the sexes only for PA in the commuting domain. For the domestic domain, females displayed a higher rate of meeting PA recommendations compared to males, and their values increased when the practice outcome of such behaviour was analyzed. Regarding the leisure and work domains, males displayed higher rates than females for both meeting PA recommendations and performing it. In general, males showed the highest rates of PA in the leisure domain, and females, in the domestic domain. Detailed
Table 1 Social and demographic characteristics among male and female residents of 26 Brazilian capitals and the Federal District $(n=53,034), 2017$

\begin{tabular}{|c|c|c|c|c|c|c|}
\hline \multirow[t]{2}{*}{ Variables } & \multicolumn{3}{|c|}{ Male $(n=19,504)$} & \multicolumn{3}{|c|}{ Female $(n=33,530)$} \\
\hline & $n$ & $\%$ & $95 \% \mathrm{CI}$ & $n$ & $\%$ & $95 \% \mathrm{CI}$ \\
\hline \multicolumn{7}{|l|}{ Age* } \\
\hline Adults (18 to 59 years old) & 12,694 & 84.7 & $83.8 ; 85.4$ & 19,078 & 80.5 & $79.8 ; 81.2$ \\
\hline Elderly (60 to 102 years old) & 6810 & 15.3 & $14.6 ; 16.2$ & 14,452 & 19.5 & $18.8 ; 20.2$ \\
\hline \multicolumn{7}{|l|}{ Marital status } \\
\hline With partner & 11,398 & 49.1 & $47.6 ; 50.1$ & 14,110 & 45.2 & $44.0 ; 46.4$ \\
\hline Without partner & 7856 & 50.9 & $49.4 ; 52.4$ & 18,801 & 54.8 & $53.6 ; 56.0$ \\
\hline \multicolumn{7}{|l|}{ Education } \\
\hline 0 to 4 years & 2199 & 12.7 & $11.7 ; 13.7$ & 5,243 & 13.6 & $12.9 ; 14.4$ \\
\hline 5 to 8 years & 2457 & 18.0 & $16.8 ; 19.3$ & 4,645 & 17.3 & $16.4 ; 18.2$ \\
\hline 9 to 11 years & 6951 & 38.8 & $37.4 ; 40.3$ & 11,077 & 36.0 & $34.9 ; 37.1$ \\
\hline 12 to 20 years & 7897 & 30.5 & $29.2 ; 31.8$ & 12,565 & 33.1 & $32.0 ; 34.3$ \\
\hline \multicolumn{7}{|l|}{ Region } \\
\hline North & 4941 & 10.6 & $10.0 ; 11.3$ & 7,485 & 9.9 & $9.5 ; 10.4$ \\
\hline Northeast & 6557 & 24.8 & $23.8 ; 25.8$ & 11,825 & 25.6 & $24.8 ; 26.3$ \\
\hline Midwest & 2844 & 11.9 & $11.0 ; 12.8$ & 5,168 & 11.4 & $10.8 ; 12.1$ \\
\hline Southeast & 3117 & 44.6 & $43.1 ; 46.3$ & 4,997 & 45.0 & $43.8 ; 46.3$ \\
\hline South & 2045 & 8.1 & $7.5 ; 8.7$ & 4,055 & 8.1 & $7.6 ; 8.5$ \\
\hline
\end{tabular}

* Total mean age: $42.4( \pm 14.1)$

$\%$, percentage of the weighted sample; $95 \% C I, 95 \%$ confidence intervals

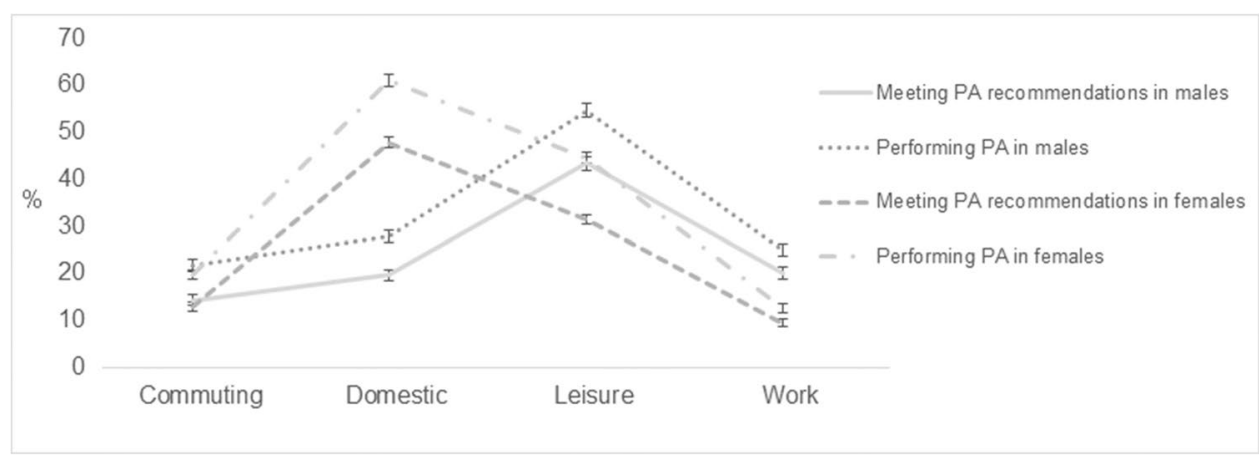

Fig. 1 Prevalence of meeting physical activity recommendations and performing active behaviour according to specific domains in males and females of 26 Brazilian capitals and the Federal District $(n=53,034), 2017$. \%: percentage of the weighted sample. $P A$, physi- cal activity. Meeting physical activity recommendations takes into account the participation of $\geq 150 \mathrm{~min} /$ week of moderate intensity or $\geq 75 \mathrm{~min} /$ week of vigorous intensity 
information related to absolute frequency $(n)$, relative frequency (with the percentage of the weighted sample), and 95\% CI of the outcomes investigated according to specific domains for males and females are available in the supplementary material.

The association between education levels and meeting PA recommendations, as well as performing active behaviour in specific domains, can be seen in Table 2 . Males with $\geq 12$ years of education were less likely to meet commuting PA recommendations $(\mathrm{OR}=0.69,95 \%$ CI: 0.48-0.98) compared to those who studied for up to 4 years. For the domestic domain, males with $\geq 12$ years of schooling were less likely to meet the recommendations for PA (OR $=0.68,95 \%$ CI: $0.52-0.91)$ and to practise this behaviour (OR $=0.73,95 \%$ CI: $0.57-0.93)$. Higher education was also associated with the two outcomes of PA at work (meeting PA recommendations: $\mathrm{OR}_{9-11 \text { years }}=0.61$, 95\% CI: $0.46-0.83 ; \mathrm{OR}_{\geq 12 \text { years }}=0.21,95 \%$ CI: $0.15-0.30$; performing PA: $\mathrm{OR}_{9-11 \text { years }}=0.64,95 \% \mathrm{CI}: 0.49-0.84$; $\mathrm{OR}_{\geq 12 \text { years }}=0.25,95 \% \mathrm{CI}: 0.18-0.34$ ). In contrast, leisure time had an inverse association in relation to the other PA domains. As the years of schooling increased, the chances for both investigation variables occurring were greater (meeting PA recommendations: $\mathrm{OR}_{9-11 \text { years }}=2.26,95 \%$ CI: $1.79-2.87 ; \mathrm{OR}_{\geq 12 \text { years }}=2.91$, 95\% CI: $2.28-3.72$; performing PA: $\mathrm{OR}_{5-8}$ years $=1.29,95 \% \mathrm{CI}: 1.01-1.63$; $\mathrm{OR}_{9-11 \text { years }}=2.54,95 \% \mathrm{CI}: 2.04-3.17 ; \mathrm{OR}_{\geq 12 \text { years }}=3.31$, 95\% CI: 2.64-4.16). When analyzing the results for females, it was observed that those who studied for 5 to 8 years were more likely to comply with commuting PA recommendations $(\mathrm{OR}=1.45,95 \% \mathrm{CI}: 1.07-1.96)$ and practise this type of behaviour (OR $=1.34,95 \% \mathrm{CI}: 1.04-1.74)$ when compared to those who had less years of education. Females with $\geq 12(\mathrm{OR}=0.41,95 \% \mathrm{CI}: 0.34-0.48)$ and $\geq 9$ years of education $\left(\mathrm{OR}_{9-11 \text { years }}=0.76,95 \% \mathrm{CI}\right.$ : $0.66-0.87$; $\mathrm{OR}_{\geq 12 \text { years }}=0.27,95 \% \mathrm{CI}: 0.23-0.32$ ) were less likely to meet domestic PA recommendations and its performance, respectively. Moreover, females with $\geq 5$ years of education had higher chances for both outcomes in the leisure domain (meeting PA recommendations: $\mathrm{OR}_{5-8 \text { years }}=1.26$, 95\% CI: $1.04-1.54 ; \mathrm{OR}_{9-11 \text { years }}=1.81,95 \%$ CI: $1.52-2.16$; $\mathrm{OR}_{\geq 12 \text { years }}=2.69,95 \% \mathrm{CI}: 2.25-3.22$; performing PA: $\mathrm{OR}_{5-8 \text { years }}=1.23,95 \% \mathrm{CI}: 1.03-1.46 ; \mathrm{OR}_{9-11 \text { years }}=1.75$, $95 \%$ CI: $1.51-2.01 ; \mathrm{OR}_{\geq 12 \text { years }}=2.94,95 \%$ CI: $2.53-3.40$ ).

\section{Discussion}

This study aimed to identify the association between educational status and PA in its specific domains according to sex. The chances of meeting PA recommendations and performing the behaviour in the domestic domain were lower in males and females with higher education. In the work domain, the two variables were associated only for males, indicating that those with higher education had fewer chances of meeting PA recommendations and performing it. However, more years of education was positively associated with meeting PA recommendations and practising the behaviour in leisure time for both sexes.

Concerning active behaviour according to education, males with more years of education had higher chances of meeting PA recommendations and performing this practice during leisure time compared to those who were less educated. These findings corroborate those from other Brazilian (Costa et al., 2010; Nunes et al., 2015) and international studies (Chau et al., 2017). This may be linked to the fact that individuals with fewer years of study have reduced knowledge about the risks of a sedentary lifestyle (Chau et al., 2013), as well as the benefits gained through the regular practice of PA (Kohl et al., 2012). In addition, the aspect of people with higher education being more active during leisure may be related to the fact that they have a different relationship with their work, which could provide them with greater time availability and greater access to activities in this domain (Bicalho et al., 2010).

Furthermore, males were more inactive and practised less in other PA domains compared to females, when taking into account all levels of education. However, when comparing years of education, the most educated males had a reduced chance of performing PA at work, at home, and for commuting. Recently, in a systematic review, seven studies $(29.1 \%)$ indicated that lower education level was associated with higher PA levels in the occupational domain, with six studies conducted with both males and females and one with only females (Rodrigues et al., 2017). Thus, an interesting way to analyze PA in this scenario is related to occupational qualification, in which individuals with higher professional qualifications tend to be more active in leisure time compared to those with lower qualifications (Zanchetta et al., 2010). In addition, due to long working hours, Taylor (2011) proposes brief breaks at work to interrupt sitting time and increase PA, even at a minor intensity. These breaks can restore, refresh, and energize workers through facilitator-led exercises, where the employee performs a series of recommended moves, walks through the halls, or climbs stairs for a fixed amount of time (Taylor, 2011). Nevertheless, despite the benefits of this strategy (such as increased productivity and reduced healthcare costs), overcoming the inertia of current standards and mobilizing management support are some of the challenges still encountered (Taylor, 2011).

Among females, it was found that the higher the level of education, the greater the chance of meeting PA recommendations and practising this active behaviour during leisure time. It is possible to observe a significant positive trend between PA in this domain and education in females (Nunes et al., 2015). As education is directly related to income, it 


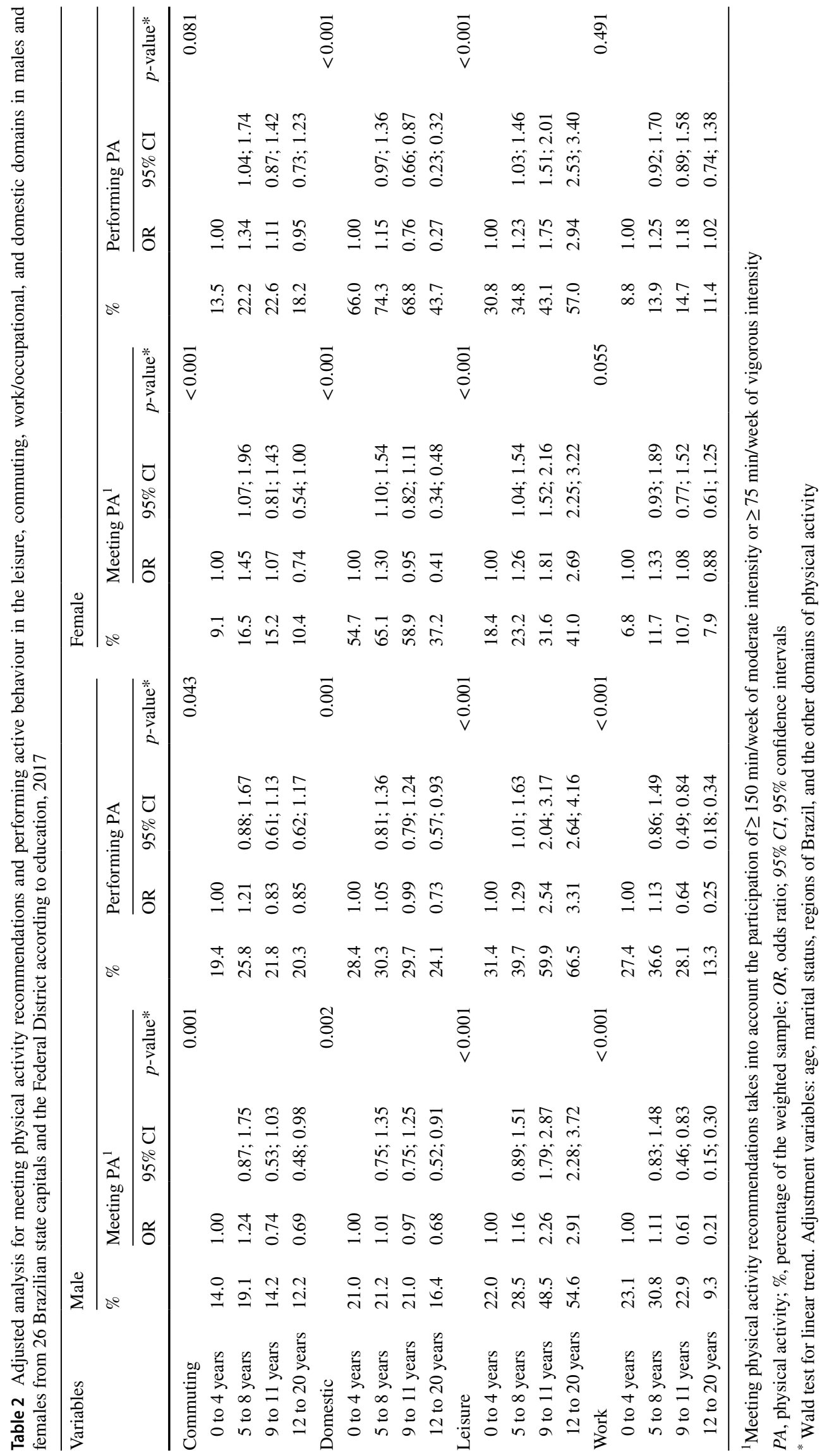


can be said that the most economically favoured individuals have greater opportunities for cultural activities and access to clubs (Paglioto \& Machado, 2012), which support PA in this domain. Furthermore, it is important to note that sedentary behaviour, such as sitting while watching television, is considered an affordable leisure option for the general population, especially among the less educated groups (Mielke et al., 2014). Thus, it is recommended that new strategies be established to provide more spaces, equipment, and practice options, so that leisure time PA can be better utilized, especially among the most vulnerable groups.

For the work and commuting domains, the proportions for the outcomes were low in females, regardless of education levels. Furthermore, only females with an education level between 5 and 8 years were more likely to comply with the PA recommendations and practise PA in these domains. A study by Malta et al. (2013) suggests that females are mostly involved in work activities that do not require physical effort. Nunes et al. (2015) describe that changes in the characterization of physical inactivity harmonize with economic development, affecting the nature of the activity behaviour; this leads to a change in energy expenditure, with the reduction of PA at work and in commuting. In the case of commuting to work, it can be said that the perception of the environment (such as aesthetics and good conditions for walking) supports the practice of PA (Sigmundová et al., 2011). In this sense, a possible explanation for the findings of the present study may be related to how participants perceive the environment that surrounds them. Therefore, researchers suggest greater investments in public policies to encourage non-motorized means of transportation, such as walking and bicycle use (Bauman et al., 2012; Guthold et al., 2018), and, especially, an increase in the quantity and quality of cycle paths, parks, and open areas that allow active commuting in a safer and more enjoyable environment.

Regarding domestic PA, females who were more educated were less likely to meet PA recommendations and perform this behaviour than those who were less educated. Overall, education is negatively associated with PA in the home environment (Costa et al., 2010; Nunes et al., 2015). As the education level is related to the socioeconomic level, it is believed that the most educated females have financial conditions that allow them to delegate their domestic activities to other people (Costa et al., 2010; Del Duca et al., 2015).

When analyzing the differences between sexes, it was possible to observe that, in general, males met PA recommendations and performed more this behaviour in the leisure and work domains, and females, in the domestic domain. This scenario is similar to the findings by Costa et al. (2010), which suggested that there was a higher prevalence of females who met the recommendations of domestic PA $(63.2 \%)$ and a low prevalence $(9 \%)$ of females who did the same in the work domain. However, only $12 \%$ of females were considered physically active at leisure time. Other researchers also found similar results in which females demonstrated the highest likelihood of meeting PA recommendations in the domestic domain (Del Duca et al., 2015; Nunes et al., 2015). According to Koyanagi et al. (2018), sex inequality can be attributed, in part, to cultural issues in which females still hold the main responsibility for household chores and childcare, spending a long time doing these activities, even when involved in other work contexts outside the home environment. Nevertheless, these issues need to be further investigated, considering that, in some cases, females with a higher education and who work outside their homes are not responsible for household chores and outsource these tasks or assign them to another family member (Del Duca et al., 2015; Malta et al., 2013). Regarding leisure time, Mielke et al. (2018) emphasize the importance of providing safe and accessible activities for females, providing higher levels of total PA and, possibly, reducing differences between males and females in order to achieve overall PA targets for 2025 .

For males, different results were observed in the literature, in which the leisure context, for example, did not present the highest prevalence for the classification of individuals as active (Costa et al., 2010; Nunes et al., 2015). In this sense, there seems to be no consensus regarding the compliance with PA recommendations in the different domains. A study conducted by Costa et al. (2010) revealed that commuting was the domain with the highest prevalence of active males (43.2\%), followed by the work (27.2\%) and the domestic domains (22.2\%). However, Nunes et al. (2015) verified that $43.6 \%$ of males met the PA recommendations at work, followed by leisure (30.9\%), domestic (29.6\%), and commuting $(27.4 \%)$ contexts. These contradictions can be explained, in part, by the diversity of instruments, cut points, and concepts of PA, in addition to the context (demographic, social, and economic) in which the individuals are selected (Bauman et al., 2012; Nunes et al., 2015), making it difficult to compare the studies. Concerning differences in the work domain, evidence suggests that males perform more moderate to vigorous PA than females (Guthold et al., 2018). Thus, job offers that involve physical effort may be more directed to the male audience. Finally, it is important to reinforce that Brazil is still a country with marked inequalities between males and females, which may reflect on the adoption and maintenance of different behaviours such as physical activity. Although it is possible to observe greater female participation in different contexts, strategies remain necessary to overcome sexist obstacles and make the society more egalitarian. It should be noted that the present study had several strengths, such as the size and representativeness of the sample and the fact that the analyses were stratified according to sex, considering that the profile of males and females is different when it comes to health issues. Moreover, considering 
the inequalities that Brazil has due to its geographic expansion, it is noteworthy that the analyses were also adjusted for the macro-regions of the country and other demographic and behavioural variables. In addition, recent information on the PA scenario in different domains considers the different levels of education of the population. However, this study was a telephonic survey, and measures regarding PA levels were self-reported, which, although advantageous due to the speed and low cost compared to other methods, may cause overestimation or underestimation of the variable. Finally, it is important to emphasize that the use of the term "compliance with PA recommendations" in this study refers to the total practice of active behaviour, without necessarily analyzing specific domains in isolation. Therefore, it was decided to review results that approached this variable from two perspectives: through the minutes practiced per week, adopting the classification according to the WHO recommendations, as well as the chance for participants to perform this activity.

\section{Conclusion}

Males demonstrated higher rates of meeting PA recommendations and practising PA in the leisure and work domains, whereas women demonstrated higher rates in the domestic domain. Additionally, males and females with more years of education had a high chance of meeting PA recommendations and performing it during leisure time. However, the chance for this behaviour in the commuting, domestic, and work domains was higher for individuals with lower education.

\section{Contributions to knowledge}

What does this study add to existing knowledge?

- In view of the current situation regarding the COVID-19 pandemic, monitoring PA pattern allows the advancement of post-pandemic strategies/actions to encourage the reduction of risky behaviours, in order to help the health and quality of life of survivors and the Brazilian population in general.

- It is relevant because specific domains of PA have different implications for the creation of mechanisms and policies to promote active behaviour in these groups.

- This study is an interdisciplinary meeting ground for cultural and behavioural approaches, considering that these aspects have an important influence on the adoption and maintenance of behaviours and life habits.
What are the key implications for public health interventions, practice or policy?

- The findings can guide the structuring, organization, and execution of programs to raise awareness, encourage PA practice in different domains, and promote healthier lifestyles through specific actions in accordance with the population's characteristics.

- These results may guide new public policies with lower expenditure and greater effectiveness by increasing active behaviour through the revitalization of spaces. Safety can also be ensured for the practice of activities such as walking, cycling, and other sports.

- As an additional factor, we also suggest initiatives that focus on encouraging new practices as well as support the maintenance of activities already being carried out.

Supplementary Information The online version contains supplementary material available at https://doi.org/10.17269/ s41997-021-00594-5.

Acknowledgements Our thanks to all participants and people involved with the research, to the Ministry of Health, and to the CAPES (Coordination for higher Education Staff Development) for research grants awarded to $\mathrm{PhD}$ students.

Author contributions All the authors participated with substantial contributions to conception of this manuscript. CB participated in the analysis and interpretation of data, and drafting the article, and approval of the final version to be published. AVBT and SNO contributed with interpretation of data, and drafting the article, and approval of the final version. GFDD contributed with critical revision of the article, and final approval of the version to be published.

Funding This work was supported by the Ministry of Health (grant number 86).

Availability of data and material Database available at http://svs.aids. gov.br/download/Vigitel/.

Code availability Not applicable.

\section{Declarations}

Conflict of interest The authors declare no competing interests.

Ethical approval All procedures performed in studies involving human participants were in accordance with the ethical standards of the institutional and/or national research committee (National Commission of Ethics in Research for Human Beings of the Ministry of Health CAAE: 65610017.1.0000.0008) and with the 1964 Helsinki declaration and its later amendments or comparable ethical standards.

Consent to participate Informed consent was obtained orally from all individual participants included in the study at the time of the telephone interviews.

Consent for publication Not applicable. 


\section{References}

Abu-Omar, K., Rütten, A., Burlacu, I., Schätzlein, V., Messing, S., $\&$ Suhrcke, M. (2017). The cost-effectiveness of physical activity interventions: A systematic review of reviews. Preventive Medicine Reports, 8, 72-78. https://doi.org/10.1016/j.pmedr. 2017.08.006

Ainsworth, B. E., Haskell, W. L., Whitt, M. C., Irwin, M. L., Swartz, A. M., Strath, S. J., ... Jacobs, D. R. (2000). Compendium of physical activities: An update of activity codes and MET intensities. Medicine \& Science in Sports \& Exercise, 32(9), S498S516. https://doi.org/10.1097/00005768-200009001-00009

Bauman, A. E., Reis, R. S., Sallis, J. F., Wells, J. C., Loos, R. J., Martin, B. W., \& Lancet Physical Activity Series Working Group. (2012). Correlates of physical activity: Why are some people physically active and others not? The Lancet, 380(9838), 258-271. https://doi.org/10.1016/s0140-6736(12)60735-1

Bicalho, P. G., Hallal, P. C., Gazzinelli, A., Knuth, A. G., \& Velásquez-Meléndez, G. (2010). Atividade física e fatores associados em adultos de área rural em Minas Gerais, Brasil. Revista De Saúde Pública, 44(5), 884-893. https://doi.org/10. 1590/s0034-89102010005000023

Brasil. Ministério da Saúde. Secretaria de Vigilância em Saúde. Departamento de Vigilância de Doenças e Agravos não Transmissíveis e Promoção da Saúde. (2018) Vigitel Brasil 2017: vigilância de fatores de risco e proteção para doenças crônicas por inquérito telefônico: estimativas sobre frequência e distribuição sociodemográfica de fatores de risco e proteção para doenças crônicas nas capitais dos 26 estados brasileiros e no Distrito Federal em 2017. Brasília: Ministério da Saúde, 2018. 130 p.

Chau, J. Y., Grunseit, A. C., Chey, T., Stamatakis, E., Brown, W. J., Matthews, C. E., ... van der Ploeg, H. P. (2013). Daily sitting time and all-cause mortality: A meta-analysis. PLOS ONE, 8(11), e80000. https://doi.org/10.1371/journal.pone.0080000

Chau, J., Chey, T., Burks-Young, S., Engelen, L., \& Bauman, A. (2017). Trends in prevalence of leisure time physical activity and inactivity: Results from Australian National Health Surveys 1989 to 2011. Australian and New Zealand Journal of Public Health, 41(6), 617-624. https://doi.org/10.1111/1753-6405. 12699

Costa, E. F., Salvador, E. P., Guimarães, V. V., \& Florindo, A. A. (2010). Atividade fisica em diferentes domínios e sua relação com a escolaridade em adultos do distrito de Ermelino Matarazzo, zona leste de São Paulo, SP. Revista Brasileira de Atividade Física \& Saúde, 15(3), 151-156. https://doi.org/10.12820/ rbafs.v.15n3p151-156

Del Duca, G. F., Nahas, M. V., Garcia, L. M. T., \& Peres, M. A. (2015). Como gênero e escolaridade interagem nos padrões de inatividade física em diferentes domínios em adultos? Revista Brasileira De Educação Física e Esporte, 29(4), 653-661. https://doi.org/10.1590/1807-55092015000400653

Gidlow, C., Johnston, L. H., Crone, D., Ellis, N., \& James, D. (2006). A systematic review of the relationship between socio-economic position and physical activity. Health Education Journal, 65(4), 338-367. https://doi.org/10.1177/0017896906069378

Gorzelitz, J., Peppard, P. E., Malecki, K., Gennuso, K., Nieto, F. J., \& Cadmus-Bertram, L. (2018). Predictors of discordance in self-report versus device-measured physical activity measurement. Annals of Epidemiology, 28(7), 427-431. https://doi.org/ 10.1016/j.annepidem.2018.03.016

Guthold, R., Stevens, G. A., Riley, L. M., \& Bull, F. C. (2018). Worldwide trends in insufficient physical activity from 2001 to 2016: A pooled analysis of 358 population-based surveys with 1.9 million participants. The Lancet Global Health, 6(10), e1077-e1086. https://doi.org/10.1016/s2214-109x(18)30357-7
He, X. Z., \& Baker, D. W. (2005). Differences in leisure-time, household, and work-related physical activity by race, ethnicity, and education. Journal of General Internal Medicine, 20(3), 259266. https://doi.org/10.1111/j.1525-1497.2005.40198.x

Johnson, B. T., \& Acabchuk, R. L. (2018). What are the keys to a longer, happier life? Answers from five decades of health psychology research. Social Science \& Medicine, 196, 218-226. https://doi.org/10.1016/j.socscimed.2017.11.001

Kohl, H. W., Craig, C. L., Lambert, E. V., Inoue, S., Alkandari, J. R., Leetongin, G., \& Lancet Physical Activity Series Working Group. (2012). The pandemic of physical inactivity: Global action for public health. The Lancet, 380(9838), 294-305. https://doi.org/10.1016/s0140-6736(12)60898-8

Koyanagi, A., Stubbs, B., \& Vancampfort, D. (2018). Correlates of low physical activity across 46 low-and middle-income countries: A cross-sectional analysis of community-based data. Preventive Medicine, 106, 107-113. https://doi.org/10.1016/j. ypmed.2017.10.023

Mahlmeister, R., Ferreira, S. G., Veloso, F., Menezes-Filho, N., \& Komatsu, B. K. (2019). Revisitando a Mobilidade Intergeracional de Educação no Brasil. Revista Brasileira De Economia, 73(2), 159-180. https://doi.org/10.5935/0034-7140.20190008

Malta, D. C., Iser, B. P. M., Claro, R. M., Moura, L. D., Bernal, R. T. I., Nascimento, A. D. F., ... Monteiro, C. A. (2013). Prevalência de fatores de risco e proteção para doenças crônicas não transmissíveis em adultos: Estudo transversal, Brasil, 2011. Epidemiologia e Serviços De Saúde, 22(3), 423-434. https://doi.org/ 10.5123/s1679-49742013000300007

Marmot, M., Friel, S., Bell, R., Houweling, T. A., Taylor, S., \& Commission on Social Determinants of Health. (2008). Closing the gap in a generation: Health equity through action on the social determinants of health. The Lancet, 372(9650), 1661-1669. https://doi.org/10.1016/s0140-6736(08)61690-6

Mielke, G. I., Silva, I. C. M., Owen, N., \& Hallal, P. C. (2014). Brazilian adults' sedentary behaviours by life domain: Populationbased study. PLoS ONE, 9(3), e91614. https://doi.org/10.1371/ journal.pone.0091614

Mielke, G. I., da Silva, I. C. M., Kolbe-Alexander, T. L., \& Brown, W. J. (2018). Shifting the physical inactivity curve worldwide by closing the gender gap. Sports Medicine, 48(2), 481-489. https://doi.org/10.1007/s40279-017-0754-7

Monteiro, C. A., Florindo, A. A., Claro, R. M., \& Moura, E. C. (2008). Validity of indicators of physical activity and sedentariness obtained by telephone survey. Revista De Saúde Pública, 42, 575-581. https://doi.org/10.1590/s0034-89102008000400001

Nunes, A. P. D. O. B., Luiz, O. D. C., Barros, M. B. A., Cesar, C. L. G., \& Goldbaum, M. (2015). Domínios de atividade física e escolaridade em São Paulo, Brasil: Estudo transversal seriado, 2003 e 2008. Cadernos De Saúde Pública, 31(8), 1743-1755. https:// doi.org/10.1590/0102-311x00130814

O’Donoghue, G., Kennedy, A., Puggina, A., Aleksovska, K., Buck, C., Burns, C., ... Boccia, S. (2018). Socio-economic determinants of physical activity across the life course: A "DEterminants of DIet and Physical ACtivity"(DEDIPAC) umbrella literature review. PLoS ONE, 13(1), e0190737. https://doi.org/10.1371/journal. pone.0190737

Paglioto, B. F., \& Machado, A. F. (2012). Perfil dos frequentadores de atividades culturais: $\mathrm{O}$ caso nas metrópoles brasileiras. Estudos Econômicos (são Paulo), 42(4), 701-730. https://doi.org/10.1590/ s0101-41612012000400003

Pinto Junior, E. P., Aquino, R., Medina, M. G., \& Silva, M. G. C. D. (2019). Efeito da Estratégia Saúde da Família nas internações por condições sensíveis à atenção primária em menores de um ano na Bahia, Brasil. Cadernos De Saúde Pública, 34(2), e00133816. https://doi.org/10.1590/0102-311x00133816 
Rodrigues, P. F., Melo, M., Assis, M., \& Oliveira, A. (2017). Condições socioeconômicas e prática de atividades físicas em adultos e idosos: uma revisão sistemática. Revista Brasileira de Atividade Física \& Saúde, 22(3), 217-232. https://doi.org/10.12820/rbafs.v. 22n3p217-232

Scholes, S., \& Bann, D. (2018). Education-related disparities in reported physical activity during leisure-time, active transportation, and work among US adults: Repeated cross-sectional analysis from the National Health and Nutrition Examination Surveys, 2007 to 2016. BMC Public Health, 18(1), 926. https://doi.org/10. 1186/s12889-018-5857-z

Sigmundová, D., El Ansari, W., \& Sigmund, E. (2011). Neighbourhood environment correlates of physical activity: A study of eight Czech regional towns. International Journal of Environmental Research and Public Health, 8(2), 341-357. https://doi.org/10. 3390/ijerph8020341

Taylor, W. C. (2011). Booster Breaks: An easy-to-implement workplace policy designed to improve employee health, increase productivity, and lower health care costs. Journal of Workplace Behavioural Health, 26(1), 70-84. https://doi.org/10.1080/15555 240.2011.540991

Viacava, F., Porto, S. M., Carvalho, C. D. C., \& Bellido, J. G. (2019). Desigualdades regionais e sociais em saúde segundo inquéritos domiciliares (Brasil, 1998-2013). Ciência \& Saúde Coletiva, 24, 2745-2760. https://doi.org/10.1590/1413-81232018247.15812017

World Health Organization. (2020). WHO 2020 guidelines on physical activity and sedentary behaviour. World Health Organization.

Zanchetta, L. M., Barros, M. B. D. A., César, C. L. G., Carandina, L., Goldbaum, M., \& Alves, M. C. G. P. (2010). Inatividade física e fatores associados em adultos, São Paulo, Brasil. Revista Brasileira De Epidemiologia, 13, 387-399. https://doi.org/10.1590/ s1415-790x2010000300003

Publisher's note Springer Nature remains neutral with regard to jurisdictional claims in published maps and institutional affiliations.

\title{
Authors and Affiliations
}

\author{
Cecília Bertuol $^{1}$ D . Alexandre Vinicius Bobato Tozetto ${ }^{1}$ (D) Silas Nery de Oliveira ${ }^{1}$ (D) Giovani Firpo Del Duca ${ }^{1}$ (D \\ Cecília Bertuol \\ bertuolcecilia@gmail.com \\ 1 Federal University of Santa Catarina, Sports Center, \\ Campus Universitário Reitor João David Ferreira Lima, \\ Florianopolis, SC, Brazil
}

